\title{
Fruit Surface Colonization and Biological Control of Postharvest Diseases of Pear by Preharvest Yeast Applications
}

\author{
Jesse M. Benbow and David Sugar, Oregon State University, Southern Oregon Research and Extension Center, \\ 569 Hanley Rd., Medford 97502
}

\begin{abstract}
Benbow, J. M., and Sugar, D. 1999. Fruit surface colonization and biological control of postharvest diseases of pear by preharvest yeast applications. Plant Dis. 83:839-844.

The yeasts Cryptococcus infirmo-miniatus, Cryptococcus laurentii, and Rhodotorula glutinis, applied to Bosc and d'Anjou pear fruit in the field 3 weeks prior to harvest, maintained high population levels through harvest, while populations of Candida oleophila declined after 1 and 2 weeks, and by harvest were not significantly different from total yeast populations on untreated fruit. Yeasts were sprayed individually on fruit at concentrations of 1 to $3 \times 10^{8} \mathrm{CFU} / \mathrm{ml}$, with approximately $2 \mathrm{ml}$ applied per fruit. Initial population sizes for all four species averaged $5 \times$ $10^{6} \mathrm{CFU}$ per fruit. C. infirmo-miniatus provided the most consistent decay control in fruit treated 3 weeks before harvest. C. infirmo-miniatus and $R$. glutinis also provided significant postharvest decay control in Bosc fruit treated 1 day before harvest.
\end{abstract}

Most postharvest disease in pear fruit (Pyrus communis) is initiated at wounds that occur during harvest or packing. Subsequent infection occurs at the wound by one of several pathogens $(17,20)$. Penicillium expansum and Botrytis cinerea (causal agents of blue mold and gray mold, respectively) are relatively aggressive, fastgrowing pathogens. Phialophora malorum, Cladosporium herbarum, and Alternaria alternata are less aggressive pathogens (causing side rots) that become problems in fruit stored for longer periods (11). Phialophora malorum and A. alternata are not sensitive to thiabendazole (TBZ) (9), the most commonly used postharvest fungicide for pome fruit in the United States. Most strains of $P$. expansum and $B$. cinerea are sensitive to TBZ, although resistant isolates are frequently encountered (15).

Several microorganisms have been discovered that are able to colonize wound sites and compete with and reduce pathogen establishment at those sites. Cryptococcus infirmo-miniatus strain YY6, Rhodotorula glutinis strain HRB6 (3), and Cryptococcus laurentii strain RR87-108 (12) are yeasts that were originally isolated from the surfaces of pear or apple fruit in the Pacific Northwest. When inoculated into wounds on pears and apples after harvest in combination with pathogens, these yeasts have provided good control of rots caused by $P$. expansum, $B$. cinerea, and

Corresponding author: D. Sugar

E-mail: David.Sugar@orst.edu

Accepted for publication 1 June 1999.

Publication no. D-1999-0621-04R

(C) 1999 The American Phytopathological Society
Phialophora malorum $(3,12,19,21)$. Candida oleophila strain I-182 has also been effective in reducing postharvest decays (7) and is the active component of the biological fungicide Aspire (Ecogen Corp., Langhorne, PA), which is registered for postharvest use on pear.

While several studies have demonstrated the potential for biocontrol of postharvest disease when applied after harvest, few have addressed the practicality of applying biocontrol agents to the fruit while in the field with the purpose of controlling postharvest decays. Spotts and Chand-Goyal (16) found that $C$. infirmo-miniatus and $C$. laurentii reduced blue mold decay when applied to pear wounds $24 \mathrm{~h}$ after inoculation with $P$. expansum, but after 72 h only provided control when combined with a fungicide. This indicates the importance of prompt application of biocontrol agents and the potential value of applying biocontrol agents in the field prior to incidence of wounding during harvest (17).

An important consideration in preharvest application of biocontrol agents is the ability of the microorganisms to survive at sufficient populations on the fruit surface after application. The weather in pear growing regions is generally hot and dry in the preharvest period, which may have detrimental effects on yeast populations. Yeast may also be adversely affected by pesticide sprays (4) or washed off the fruit surface during irrigation or spraying. However, since these yeasts were originally isolated from fruit surfaces after or near harvest $(3,12)$, they might be tolerant of these conditions. Some yeasts can colonize plant surfaces or wounds for long periods under dry conditions and produce extracellular polysaccharides that enhance their survival and restrict pathogen colonization sites $(8,24)$.
The objectives of this work were to study the survival of the specific yeast biocontrol agents on fruit when applied prior to harvest, and to determine the ability of biocontrol agents applied prior to harvest to control postharvest decay on wounded pears during cold storage.

\section{MATERIALS AND METHODS}

Culture and preparation of biocontrol agents. The yeasts $C$. infirmo-miniatus, $R$. glutinis, and $C$. laurentii were used in 1996. These yeasts plus Candida oleophila, isolated from Aspire, were included in the experiment in 1997. Cultures of $C$. infirmo-miniatus and $R$. glutinis were supplied by R. A. Spotts (Mid-Columbia Agricultural Research and Extension Center, Hood River, OR). A culture of C. laurentii was provided by R. G. Roberts (USDA, Wenatchee, WA).

Yeast cultures stored at $-20^{\circ} \mathrm{C}$ were activated by pouring $1 \mathrm{ml}$ of thawed suspension into $75 \mathrm{ml}$ of yeast malt dextrose broth (YMDB: $3 \mathrm{~g}$ of malt extract, $3 \mathrm{~g}$ of yeast extract, $5 \mathrm{~g}$ of peptone, and $10 \mathrm{~g}$ of dextrose per liter of medium). The suspensions were incubated on a shaker for 2 days at $20^{\circ} \mathrm{C}$. After incubation, $0.1-\mathrm{ml}$ aliquots of each yeast were spread on petri dishes containing yeast malt dextrose agar (YMDA: YMDB plus $18 \mathrm{~g}$ of agar per liter) and incubated for 2 to 3 days at room temperature. The colonies were then scraped from the plates with a sterile rubber spatula and suspended in sterile distilled water. Suspensions of $C$. laurentii were adjusted to a concentration of 2.8 to $3.3 \times 10^{8} \mathrm{CFU} / \mathrm{ml}$ by adjusting to $2 \%$ transmittance at $595 \mathrm{~nm}$ using a Spectronic 20 spectrophotometer. Suspensions of $C$. infirmo-miniatus and $R$. glutinis were adjusted to 1.0 to $1.5 \times 10^{8} \mathrm{CFU} / \mathrm{ml}$ by adjusting to $2 \%$ transmittance at $550 \mathrm{~nm}$, and Candida oleophila was adjusted to approximately $1 \times 10^{8} \mathrm{CFU} / \mathrm{ml}$ by adjusting to $2 \%$ transmittance at $550 \mathrm{~nm}$ and diluting by one-half. Spectrophotometric determinations of yeast concentrations were confirmed by dilution plating of treatment suspensions.

Fruit. Pear fruit (cvs. Bosc and d'Anjou) were grown at the Southern Oregon Research and Extension Center in Medford, Oregon. In addition to being the principal winter pear cultivars of the $\mathrm{Pa}$ cific Northwest, d'Anjou and Bosc present contrasting fruit surfaces, which could potentially impact the survival of microor- 
ganisms. d'Anjou pears have a smooth, waxy surface, while Bosc pears are coarsely russetted. Trees for treatment with each yeast species and untreated controls were selected at random throughout 0.5-ha blocks of each cultivar. The orchards were managed under a commercial spray program with under-tree sprinkler irrigation. Yeast suspensions were applied to fruit on the tree using a hand-held spray bottle, at a rate of approximately $2 \mathrm{ml}$ per fruit. Ap- proximately 30 fruit on each tree received the yeast application. Each treatment was replicated five times in 1996 and four times in 1997, with each tree as a replicate.

Yeast applications for population sampling were made 3 weeks prior to harvest (Bosc: 20 August 1996 and 13 August 1997; Anjou: 23 August 1996 and 13 August 1997). Yeast were also applied in the same manner to a separate set of fruit 1 day prior to harvest for postharvest patho-
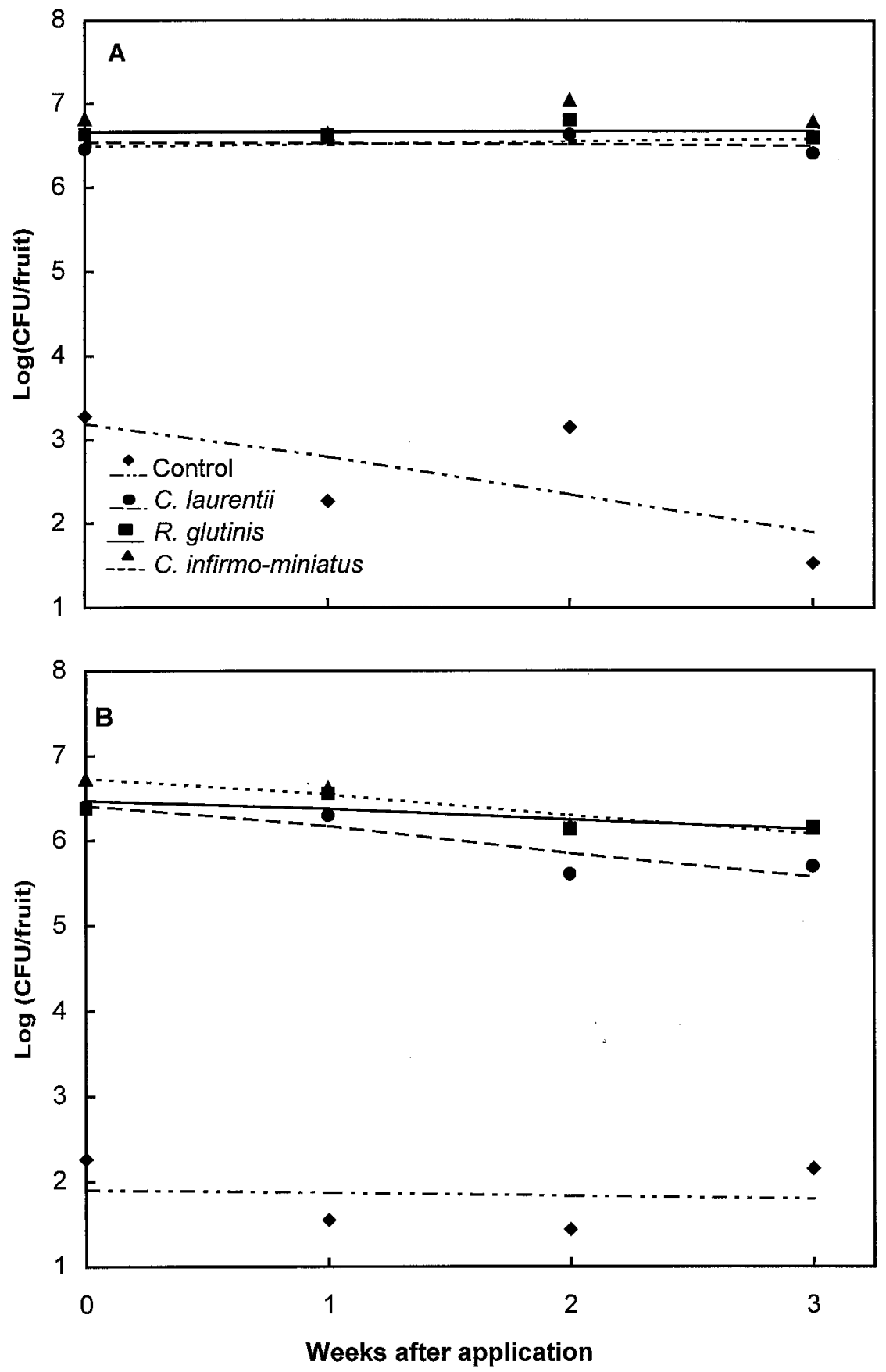

Fig. 1. Populations of yeast biocontrol agents applied 3 weeks before harvest to (A) d'Anjou and (B) Bosc pear fruit in 1996. Yeasts were sprayed onto fruit at concentrations of 1 to $3 \times 10^{8} \mathrm{CFU} / \mathrm{ml}$, with approximately $2 \mathrm{ml}$ applied per fruit. d'Anjou: control: $Y=-0.065 X+3.19, R^{2}=0.06, P(b=0)$ $=0.272 ;$ Cryptococcus laurentii: $Y=-0.002 X+6.54, R^{2}=0.00, P(b=0)=0.825 ;$ Rhodotorula glutinis: $Y=0.001 X+6.66, R^{2}=0.00, P(b=0)=0.914 ; C$. infirmo-miniatus: $Y=0.005 X+6.77, R^{2}=$ $0.02, P(b=0)=0.649$. Bosc: control: $Y=-0.005 X+1.90, R^{2}=0.00, P(b=0)=0.931 ;$ C. laurentii: $Y=-0.040 X+6.41, R^{2}=0.42, P(b=0)=0.002 ;$. glutinis: $Y=-0.016 X+6.47, R^{2}=0.13, P(b=0)$ $=0.122 ;$ C. infirmo-miniatus: $Y=-0.031 X+6.73, R^{2}=0.00, P(b=0)=0.006$. gen inoculation tests. Climatic data were collected during the field experiments by an AgriMet weather station (U.S. Bureau of Reclamation) located approximately 250 $\mathrm{m}$ from the experimental orchard.

Population sampling. Three uniformsized fruit from each replicate were sampled once per week to determine the number of yeast CFU on the fruit surface. The three fruit were combined in beakers containing $900 \mathrm{ml}$ of $0.05 \mathrm{M}$ sterile phosphate buffer (SPB) with $0.006 \%$ (vol/vol) Tween 20. The fruit and buffer were stirred for 5 min using a magnetic stirrer and then placed in a sonicating bath for $5 \mathrm{~min}(2)$. A $1-\mathrm{ml}$ sample was removed from each beaker immediately after sonication, and 10 -fold dilutions were made to $10^{-5}$ in SPB.

Samples of each dilution were then placed on petri dishes containing a selective, dilute YMDA medium (1.5 g of malt extract, $1.5 \mathrm{~g}$ of yeast extract, $2.5 \mathrm{~g}$ of peptone, $5 \mathrm{~g}$ of dextrose, and $18 \mathrm{~g}$ of agar per liter of medium, with 100 ppm chloramphenicol, $50 \mathrm{ppm}$ ampicillin, and 2 ppm dichloran). Chloramphenicol and ampicillin were included to inhibit bacterial growth; dichloran was used to inhibit radial growth of filamentous fungi. The plates were incubated for 2 to 3 days at room temperature. After incubation, population levels were determined using the plate-dilution frequency technique of Harris and Sommers (6). The four yeast species used in this experiment exhibit distinct colony color and morphological characteristics, which were used to visually distinguish the different species. For a given treatment, only yeast species that were applied to that treatment were counted in the population samples. To determine population levels on the untreated controls, only colonies resembling those of the yeast species used in the treatments were counted.

Control of postharvest decay. Ten fruit from each replicate to be used for postharvest treatment were randomly selected from the harvested samples. Each fruit was wounded five times with the sterile head of a finishing nail $(6 \mathrm{~mm}$ diameter $\times 3 \mathrm{~mm}$ deep), then placed into cold storage at $0.5^{\circ} \mathrm{C}$ for up to 4 months. In 1996 , only fruit that were sprayed with biocontrol agents 1 day before harvest were wounded for postharvest experiments. In 1997, fruit sprayed both 3 weeks and 1 day before harvest were included.

Lesions on the fruit were counted, and the type of decay was determined visually after 2 and 4 months of storage at $-0.5^{\circ} \mathrm{C}$. The types of decay were divided into three categories and recorded as blue mold ( $P$. expansum), gray mold (B. cinerea), or side rot (Cladosporium herbarum, A. alternata, or Phialophora malorum). The latter three were combined because they are indistinguishable on pear by symptomatology alone. These 
side rot fungi are relatively slow-growing wound pathogens, inciting lesions that appear after 3 or more months storage of pears at $-0.5^{\circ} \mathrm{C}(9,18)$.

Statistical analysis. Populations were examined for significant differences among treatments using $95 \%$ confidence intervals, where nonoverlapping confidence intervals indicate a significant difference. Postharvest decay data were analyzed by ANOVA; Fisher's least significant difference procedure was used to distinguish significant differences among treatment means, except that a $t$ test was used to compare decay incidence between treatments applied 3 weeks and 1 day preharvest in 1997.
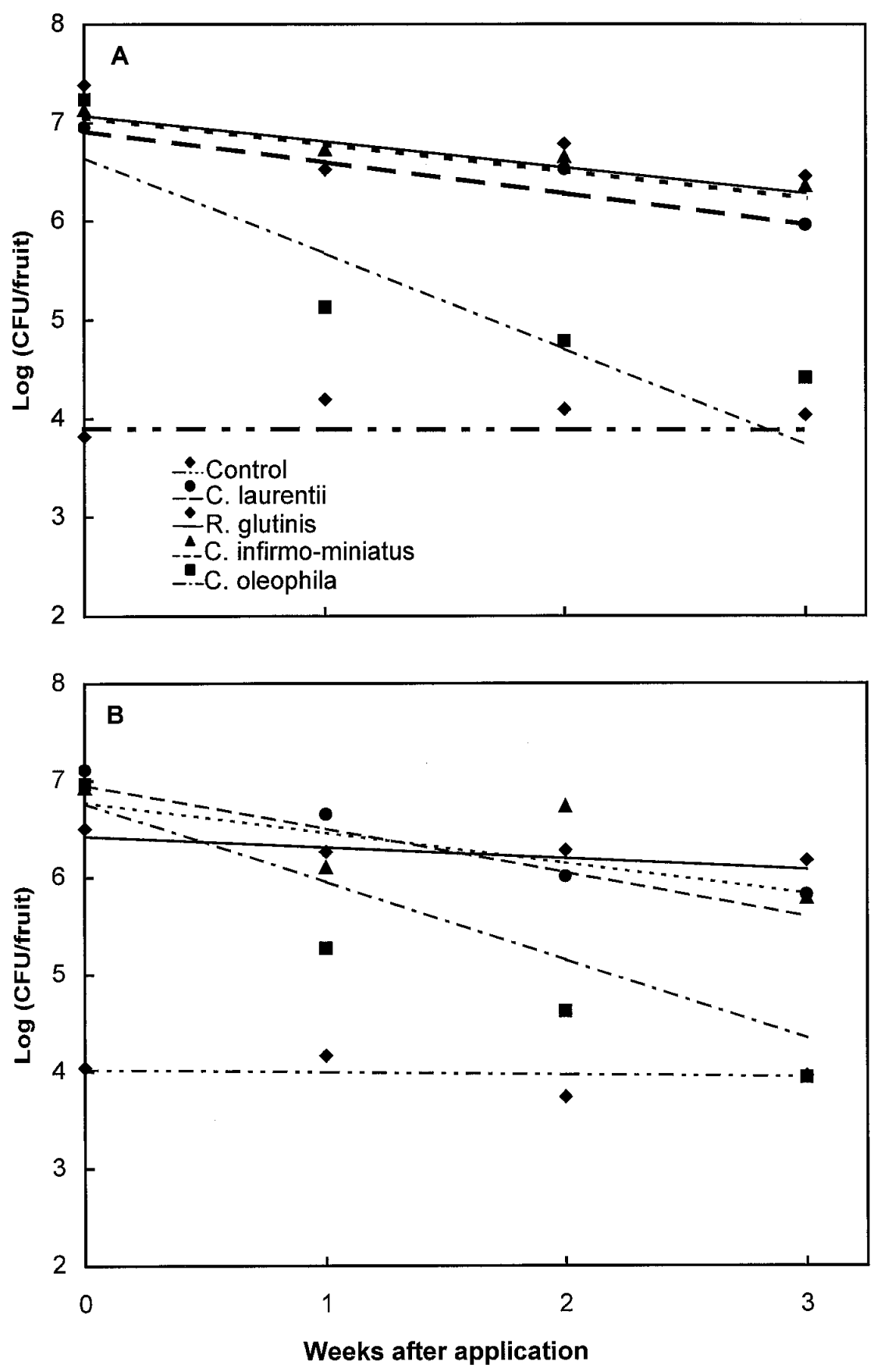

Fig. 2. Populations of yeast biocontrol agents applied 3 weeks before harvest to (A) d'Anjou and (B) Bosc pear fruit in 1997. Yeasts were sprayed onto fruit at concentrations of 1 to $3 \times 10^{8} \mathrm{CFU} / \mathrm{ml}$, with approximately $2 \mathrm{ml}$ applied per fruit. d'Anjou: control: $Y=-0.001 X+3.90, R^{2}=0.10, P(b=0)$ $=0.228 ;$ Cryptococcus laurentii: $Y=-0.045 X+6.91, R^{2}=0.57, P(b=0)=0.005 ;$ Rhodotorula glutinis: $Y=-0.038 X+7.07, R^{2}=0.34, P(b=0)=0.037 ; C$. infirmo-miniatus: $Y=-0.039 X+7.05, R^{2}=$ $0.57, P(b=0)=0.001$; Candida oleophila: $Y=-0.138 X+6.64, R^{2}=0.73, P(b=0)=0.000$. Bosc: control: $Y=-0.062 X+4.14, R^{2}=0.01, P(b=0)=0.193 ; C$. laurentii: $Y=-0.064 X+6.95, R^{2}=0.72$, $P(b=0)=0.001 ; R$. glutinis: $Y=-0.016 X+6.42, R^{2}=0.24, P(b=0)=0.053 ; C$. infirmo-miniatus: $Y$ $=-0.044 X+6.77, R^{2}=0.40, P(b=0)=0.009 ;$ Candida oleophila: $Y=-0.190 X+6.94, R^{2}=0.93$, $P(b=0)=0.000$.

\section{RESULTS}

Colonization of fruit surfaces. In 1996, all three yeast species maintained populations at high levels throughout the duration of the experiment on both pear varieties (Fig. 1). There were no significant differences in population among the three yeasts, and all had significantly higher populations than the control. Initial populations on d'Anjou pears ranged from $2.9 \times 10^{6} \mathrm{CFU}$ per fruit $\left(C\right.$. laurentii) to $7.5 \times 10^{6}(C$. infirmo-miniatus). Three weeks after application, population numbers were relatively unchanged, ranging from $3.3 \times 10^{6} \mathrm{CFU}$ per fruit $\left(C\right.$. laurentii) to $7.2 \times 10^{6}(C$. infirmo-miniatus). On treated Bosc pears, initial population levels for the three yeasts ranged from $2.8 \times 10^{6} \mathrm{CFU}$ per fruit $(R$. glutinis) to $6.8 \times 10^{6}$ (C. infirmo-miniatus). After 3 weeks, populations varied from 8.9 $\times 10^{5} \mathrm{CFU}$ per fruit (C. laurentii) to $1.8 \times$ $10^{6}$ (R. glutinis). Populations of yeast on untreated d'Anjou pears averaged $2.0 \times 10^{3}$ CFU per fruit initially and $32 \mathrm{CFU}$ per fruit at the end of the experiment. On Bosc pears, initial populations averaged $2.0 \times$ $10^{2} \mathrm{CFU}$ per fruit, ending at $3.2 \times 10^{2} \mathrm{CFU}$ per fruit (Fig. 1).

In 1997, the three species used in 1996 behaved similarly to the previous year, with yeast populations on treated fruit remaining significantly higher than those on the control fruit throughout the experiment (Fig. 2). While populations of C. laurentii, $C$. infirmo-miniatus, and $R$. glutinis on d'Anjou fruit remained high (final populations from $9.2 \times 10^{5}$ to $2.9 \times 10^{6}$ CFU per fruit), populations of Candida oleophila declined rapidly. After 2 weeks, the population of Candida oleophila on fruit was not significantly different from the untreated control, and after 3 weeks the population averaged $2.6 \times 10^{4} \mathrm{CFU}$ per fruit. On Bosc pears, the yeast populations showed similar patterns. Initial populations for $C$. laurentii, $C$. infirmo-miniatus, $R$. glutinis, and Candida oleophila were not significantly different and ranged from 3.2 $\times 10^{6} \mathrm{CFU}$ per fruit (R. glutinis) to $1.3 \times$ $10^{7}$ (C. laurentii). Throughout the 3 -week study, populations of $C$. laurentii, $C$. infirmo-miniatus, and $R$. glutinis remained significantly higher than untreated fruit, and final populations ranged from $6.2 \times$ $10^{5} \mathrm{CFU}$ per fruit (C. laurentii) to $1.5 \times$ $10^{6}$ (R. glutinis). However, the populations of Candida oleophila dropped quickly after application and at the end of the experiment were $8.8 \times 10^{3} \mathrm{CFU}$ per fruit, not significantly different from the untreated fruit. Climatic data collected during the 3 weeks prior to harvest in each year are shown in Figure 3.

Storage decay. In Bosc pears in 1996, sprays with $C$. laurentii and $C$. infirmominiatus 1 day before harvest resulted in significantly lower levels of total decay than in the untreated control or in fruit treated with $R$. glutinis. There were no significant differences in total decay con- 
trol among treatments in d'Anjou fruit in 1996, but $C$. infirmo-miniatus significantly reduced incidence of gray mold and side rot (Table 1). In 1997, Bosc pears sprayed with $R$. glutinis or $C$. infirmo-miniatus 1 day before harvest had significantly lower levels of decay than did the unsprayed control fruit, while there were no significant differences in d'Anjou. C. infirmominiatus provided significant inhibition of total decay on Bosc and d'Anjou pears, and $R$. glutinis inhibited total decay on d'Anjou pears sprayed 3 weeks before harvest (Table 1). Decay incidence did not differ between treatments of $R$. glutinis, $C$. infirmo-miniatus, or C. laurentii applied 3 weeks or 1 day before harvest. However, incidence of gray mold was significantly lower $(P<0.05)$ in both Bosc and d'Anjou fruit sprayed with Candida oleophila 1 day before harvest compared with fruit sprayed 3 weeks before harvest. Incidence of side rot in d'Anjou fruit sprayed with Candida oleophila 1 day preharvest was greater than in fruit sprayed 3 weeks preharvest.

Decay incidence and the types of decay observed varied between years and cultivars (Table 1). There were no apparent
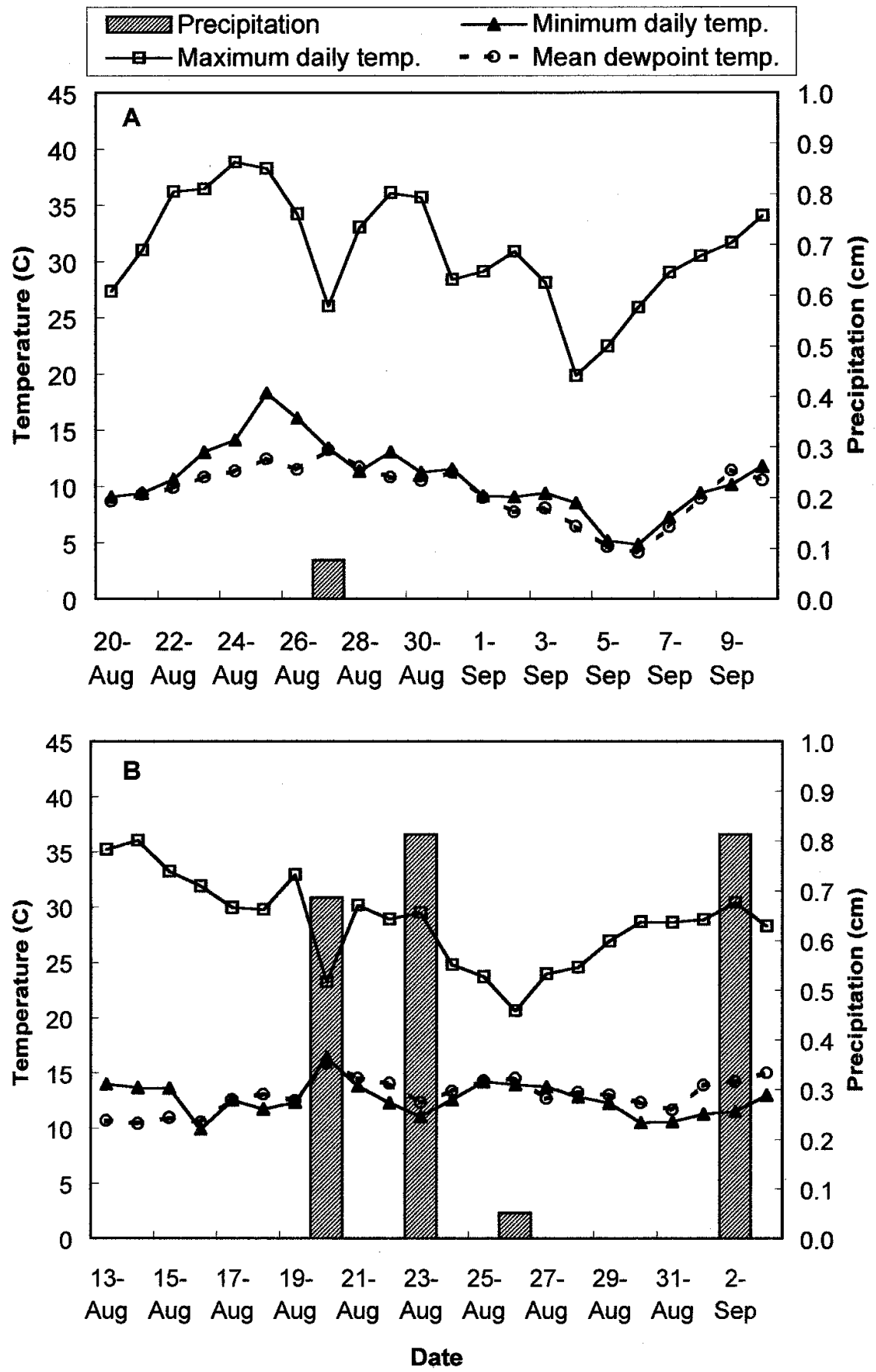

Fig. 3. Daily maximum and minimum temperatures, mean dew point temperatures, and precipitation during the 3 weeks prior to harvest in 1996 and 1997 at the Southern Oregon Research and Extension Center, Medford.

trends among yeast biocontrol agents toward providing superior control of a particular type of decay.

\section{DISCUSSION}

The yeasts $C$. infirmo-miniatus, $C$. laurentii, and $R$. glutinis survived on the surface of pear fruit at high, relatively stable population levels for at least 3 weeks before harvest under typical hot and dry climatic conditions, while Candida oleophila was unable to maintain a stable population on the fruit surface during this period. However, $C$. infirmo-miniatus was the only yeast that provided significant decay control in both pear cultivars when applied 3 weeks before harvest. Since $C$. infirmominiatus, $C$. laurentii, and $R$. glutinis were recovered from fruit at similar population levels 3 weeks after they were applied, it may be that exposure to field conditions differentially affects their ability to colonize fruit wounds or to compete successfully with pathogens, even though all were able to grow on a rich culture medium. Significant biocontrol of total decay was observed in Bosc in 1996 and in both application timings in 1997, while control was only significant in d'Anjou in the 3week preharvest application timing in 1997. It is possible that the russet surface of Bosc pears provides more protected locations for yeast colonists than the smooth surface of d'Anjou pears, allowing yeasts to better maintain their biocontrol capacity.

Improved control of gray mold by Candida oleophila applied 1 day before harvest compared to 3 weeks before harvest probably reflects the differences in yeast population levels expected to be present at harvest following each treatment (Fig. 2). Reasons for the higher incidence of side rot in d'Anjou following Candida oleophila treatment 1 day before harvest are not apparent.

The yeasts applied as treatments made up the majority of the yeast populations recovered from the untreated fruit. These yeasts may have been transported to the fruit by spray drift, insects, or splashing rain. They may also have been part of the original epiphytic community on the fruit. The fruit were not sampled prior to treatment to determine which species were common epiphytes in the orchard. However, in a previous survey, Chand-Goyal and Spotts (4) found that pear orchards in the Pacific Northwest typically support epiphytic yeast populations made up of from three to seven morphologically distinct species. Typical total yeast populations in their study ranged from $3.5 \times 10^{2}$ to $7.4 \times 10^{3} \mathrm{CFU}$ per square centimeter of fruit surface, and varied depending on orchard location, degree of cultivation, and spray practices. $R$. glutinis was the only one of the four species used in our study that was found on fruit from the Medford area in their survey. Leibinger et al. (10) 
found that a labeled strain of $R$. glutinis spread from inoculated trees to establish relatively low populations in nearby uninoculated trees and speculated that splashing rainfall was the dispersal mechanism.

Leibinger et al. (10) used various combinations of $R$. glutinis strain CF35, Aureobasidium pullulans strains $\mathrm{CF} 10$ and CF40, and the bacterium Bacillus subtilis strains AG704 and HG77 in preharvest applications on apples to control bulls-eye rot (caused by Pezicula malicorticis), as well as blue mold and gray mold. The microbial antagonists were able to colonize the fruit and provided significant reductions in average postharvest lesion sizes when compared with unsprayed fruit. The mixture of $R$. glutinis with A. pullulans suppressed decay in apple to the same extent as the fungicide Euparen, commonly used in Europe (9).

Teixidó et al. (22) reported reduction of blue mold incidence in apples treated 2 days before harvest with Candida sake strain CPA-1. Cells of this yeast strain modified for tolerance to low water activity by culture in high-glucose or high-glycerol media increased in number on the fruit surface, while numbers of unmodified cells remained relatively unchanged. Cells tolerant to low water activity also controlled decay better than did unmodified cells.

The mechanisms by which yeast biocontrol agents provide decay control are not fully understood. However, there is evidence that the mode of action of several yeast species used as biocontrol agents does not involve antibiosis but rather competition for nutrients at the wound site $(3,5)$.

Because most decay originates at wounds caused during and immediately after harvest $(17,20)$, application of biocontrol agents as close as possible to the time of wounding should provide the agent with an opportunity to protect the fruit at the wound site $(13,14,23)$. By applying biocontrol agents with the ability to survive on the fruit prior to harvest, the biocontrol agents may be available to colonize wounds quickly and exclude decay-causing organisms from a critical nutrient base. In addition, yeast on the fruit surface may be able to reduce incidence of latent infections by pathogens that do not require wounds for infection (1). Use of biocontrol agents with the ability to survive for extended periods on the fruit surface can also provide the grower with flexibility in scheduling treatment and harvest dates.

\section{ACKNOWLEDGMENTS}

We thank Sanda Collegio, Kate Powers, and Sally Basile for technical assistance, and R. A. Spotts and R. G. Roberts for providing yeast cultures and advice. This research was supported by the Winter Pear Control Committee and the Oregon Center for Applied Agricultural Research. Oregon Agricultural Experiment Station technical paper 11521.

\section{LITERATURE CITED}

1. Biggs, A. R. 1995. Detection of latent infections in apple fruit with paraquat. Plant Dis. 79:1062-1067.

2. Chand-Goyal, T., and Spotts, R. A. 1994. A standard method for studying the microbial ecology of fruits. (Abstr.) Phytopathology 84:1083.

3. Chand-Goyal, T., and Spotts, R. A. 1996. Control of postharvest pear diseases using natural saprophytic yeast colonists and their combination with a low dosage of thiabendazole. Postharvest Biol. Technol. 7:51-64.

4. Chand-Goyal, T., and Spotts, R. A. 1996. Enumeration of bacterial and yeast colonists of apple fruits and identification of epiphytic yeasts on pear fruits in the Pacific Northwest United States. Microbiol. Res. 151:427-432.

5. Droby, S., and Chalutz, E. 1994. Mode of action of biocontrol agents of postharvest diseases. Pages 63-75 in: Biological Control of Postharvest Diseases - Theory and Practice. C. L. Wilson and M. E. Wisniewski, eds. CRC
Press, Boca Raton, FL.

6. Harris, R. F., and Sommers, L. E. 1968. Platedilution frequency technique for assay of microbial ecology. Appl. Microbiol. 16:330-334.

7. Hofstein, R., Fridlender, B., Chalutz, E., and Droby, S. 1994. Large-scale production and pilot testing of biological control agents for postharvest diseases. Pages 89-100 in: Biological Control of Postharvest Diseases Theory and Practice. C. L. Wilson and M. E. Wisniewski, eds. CRC Press, Boca Raton, FL.

8. Janisiewicz, W. J. 1988. Biological control of diseases of fruit. Pages 153-165 in: Biocontrol of Plant Diseases, Vol. II. K. G. Mukergi and K. L. Garg, eds. CRC Press, Boca Raton, FL.

9. Jones, A. L., and Aldwinkle, H. S., eds. 1991 Compendium of Apple and Pear Diseases. American Phytopathological Society, St. Paul, MN

10. Leibinger, W., Breuker, B., Hahn, M., and Mendgen, K. 1997. Control of postharvest pathogens and colonization of the apple surface by antagonistic microorganisms in the field. Phytopathology 87:1103-1110.

11. Pierson, C. F., Ceponis, M. J., and McColloch, L. P. 1971. Market diseases of apples, pears, and quinces. U.S. Dep. Agric. Agric. Handb. 376.

12. Roberts, R. G. 1990. Postharvest biological control of gray mold of apple by Cryptococcus laurentii. Phytopathology 80:526-530.

13. Roberts, R. G. 1994. Integrating biological control into postharvest disease management strategies. HortScience 29:758-762.

14. Smilanick, J. L. 1994. Strategies for the isolation and testing of biocontrol agents. Pages 25-41 in: Biological Control of Postharvest Diseases - Theory and Practice. C. L. Wilson and M. E. Wisniewski, eds. CRC Press, Boca Raton, FL.

15. Spotts, R. A., and Cervantes, L. A. 1986 Populations, pathogenicity, and benomyl resistance of Botrytis spp., Penicillium spp., and Mucor piriformis in packinghouses. Plant Dis. 70:106-108.

16. Spotts, R. A., and Chand-Goyal, T. 1997. Combinations of biocontrol yeasts and eradicant activity of yeasts for postharvest pear diseases. (Abstr.) Phytopathology 87:S93.

17. Spotts, R. A., Sanderson, P. G., Lennox, C. L., Sugar, D., and Cervantes, L. A. 1998 Wounding, wound healing and staining of mature pear fruit. Postharvest Biol. Technol.

Table 1. Postharvest decay in Bosc and d'Anjou pears following field treatments with yeast biocontrol agents and artificial wounding

\begin{tabular}{|c|c|c|c|c|c|c|c|c|c|c|}
\hline \multirow[b]{3}{*}{ Year } & \multirow{3}{*}{$\begin{array}{c}\text { Application } \\
\text { timing }\end{array}$} & \multirow[b]{3}{*}{ Treatment $^{\mathrm{z}}$} & \multicolumn{8}{|c|}{ Percent wounds infected ${ }^{y}$} \\
\hline & & & \multicolumn{4}{|c|}{ Bosc } & \multicolumn{4}{|c|}{ d'Anjou } \\
\hline & & & Gray mold & Blue mold & Side rot & Total decay & Gray mold & Blue mold & Side rot & Total decay \\
\hline \multirow[t]{4}{*}{1996} & 1 day & Control & $29.0 \mathrm{a}$ & $21.5 \mathrm{~b}$ & $33.9 \mathrm{a}$ & $84.4 \mathrm{a}$ & $11.4 \mathrm{a}$ & $11.7 \mathrm{a}$ & $11.3 \mathrm{ab}$ & $34.4 \mathrm{a}$ \\
\hline & preharvest & R. glutinis & $10.6 \mathrm{~b}$ & $49.2 \mathrm{a}$ & $25.7 \mathrm{a}$ & $85.6 \mathrm{a}$ & $4.3 \mathrm{ab}$ & $22.4 \mathrm{a}$ & $18.1 \mathrm{ab}$ & $44.8 \mathrm{a}$ \\
\hline & & C. inf.-min. & $9.1 \mathrm{~b}$ & $9.5 \mathrm{~b}$ & $27.0 \mathrm{a}$ & $45.6 \mathrm{~b}$ & $2.7 \mathrm{~b}$ & $16.1 \mathrm{a}$ & $5.6 \mathrm{~b}$ & $24.4 \mathrm{a}$ \\
\hline & & C. laurentii & $10.8 \mathrm{~b}$ & $15.3 \mathrm{~b}$ & $25.1 \mathrm{a}$ & $51.2 \mathrm{~b}$ & $7.7 \mathrm{ab}$ & $18.9 \mathrm{a}$ & $19.8 \mathrm{a}$ & $46.4 \mathrm{a}$ \\
\hline \multirow[t]{10}{*}{1997} & 3 weeks & Control & $13.1 \mathrm{a}$ & $3.9 \mathrm{a}$ & $14.6 \mathrm{ab}$ & $31.7 \mathrm{a}$ & $7.0 \mathrm{ab}$ & $10.5 \mathrm{a}$ & $8.1 \mathrm{a}$ & $25.6 \mathrm{a}$ \\
\hline & preharvest & R. glutinis & $5.5 \mathrm{ab}$ & $1.3 \mathrm{a}$ & $14.0 \mathrm{ab}$ & $20.8 \mathrm{ab}$ & $5.0 \mathrm{ab}$ & $2.3 \mathrm{ab}$ & $1.3 \mathrm{~b}$ & $8.6 \mathrm{bc}$ \\
\hline & & C. inf.-min. & $4.0 \mathrm{~b}$ & $1.0 \mathrm{a}$ & $1.7 \mathrm{~b}$ & $6.7 \mathrm{~b}$ & $1.0 \mathrm{~b}$ & $1.0 \mathrm{~b}$ & $4.3 \mathrm{ab}$ & $6.3 \mathrm{c}$ \\
\hline & & C. laurentii & $4.0 \mathrm{~b}$ & $1.7 \mathrm{a}$ & $21.7 \mathrm{a}$ & $27.4 \mathrm{a}$ & $5.3 \mathrm{ab}$ & $0.0 \mathrm{~b}$ & $9.7 \mathrm{a}$ & $15.0 \mathrm{abc}$ \\
\hline & & C. oleophila & $16.7 \mathrm{a}^{*}$ & $1.7 \mathrm{a}$ & $24.5 \mathrm{a}$ & $44.9 \mathrm{a}$ & $15.0 \mathrm{a}^{*}$ & $5.0 \mathrm{ab}$ & $1.3 \mathrm{~b}^{*}$ & $21.3 \mathrm{ab}$ \\
\hline & 1 day & Control & $16.0 \mathrm{a}$ & $1.0 \mathrm{a}$ & $25.0 \mathrm{a}$ & $42.0 \mathrm{a}$ & $2.0 \mathrm{a}$ & $3.0 \mathrm{a}$ & $11.7 \mathrm{a}$ & $16.7 \mathrm{a}$ \\
\hline & preharvest & $R$. glutinis & $3.0 \mathrm{~b}$ & $1.3 \mathrm{a}$ & $11.3 \mathrm{a}$ & $15.5 \mathrm{~b}$ & $1.0 \mathrm{a}$ & $4.0 \mathrm{a}$ & $13.2 \mathrm{a}$ & $18.2 \mathrm{a}$ \\
\hline & & C. inf.-min. & $3.0 \mathrm{~b}$ & $0.0 \mathrm{a}$ & $8.5 \mathrm{a}$ & $11.5 \mathrm{~b}$ & $0.0 \mathrm{a}$ & $0.0 \mathrm{a}$ & $10.0 \mathrm{a}$ & $10.0 \mathrm{a}$ \\
\hline & & C. laurentii & $5.0 \mathrm{~b}$ & $0.0 \mathrm{a}$ & $14.8 \mathrm{a}$ & $19.8 \mathrm{ab}$ & $1.7 \mathrm{a}$ & $6.0 \mathrm{a}$ & $10.0 \mathrm{a}$ & $17.7 \mathrm{a}$ \\
\hline & & C. oleophila & $3.0 \mathrm{~b}^{*}$ & $1.3 \mathrm{a}$ & $12.5 \mathrm{a}$ & $16.8 \mathrm{ab}$ & $0.0 \mathrm{a}^{*}$ & $5.3 \mathrm{a}$ & $14.7 \mathrm{a}^{*}$ & $19.9 \mathrm{a}$ \\
\hline
\end{tabular}

${ }^{y}$ For each year and application timing, values within a column followed by the same letter are not significantly different $(P>0.05)$ according to Fisher's protected LSD procedure. Data were transformed to arcsine (square root) prior to analysis. Differences between corresponding values for 3 weeks preharvest and 1 day preharvest in 1997 were not significantly different except where noted by asterisk.

${ }^{\mathrm{z}}$ Fruit were sprayed with yeast suspensions containing Rhodotorula glutinis $\left(1.0\right.$ to $\left.1.5 \times 10^{8} \mathrm{CFU} / \mathrm{ml}\right)$, Cryptococcus infirmo-miniatus $\left(1.0\right.$ to $1.5 \times 10^{8}$ $\mathrm{CFU} / \mathrm{ml})$, Cryptococcus laurentii $\left(2.8\right.$ to $\left.3.3 \times 10^{8} \mathrm{CFU} / \mathrm{ml}\right)$, or Candida oleophila $\left(1.0 \times 10^{8} \mathrm{CFU} / \mathrm{ml}\right)$. 
13:27-36.

18. Sugar, D., and Powers, K. 1986. Interactions among fungi causing postharvest decay of pear. Plant Dis. 70:1132-1134.

19. Sugar, D., Roberts, R. G., Hilton, R. J., Righetti, T. L., and Sanchez, E. E. 1994. Integration of cultural methods with yeast treatment for control of postharvest fruit decay in pear. Plant Dis. 78:791-795.

20. Sugar, D., and Spotts, R. A. 1993. The im- portance of wounds in infection of pear fruit by Phialophora malorum and the role of hydrostatic pressure in spore penetration of wounds. Phytopathology 83:1083-1086.

21. Sugar, D., and Spotts, R. A. 1999. Control of postharvest decay in pear by four laboratorygrown yeasts and two registered biocontrol products. Plant Dis. 83:155-158.

22. Teixidó, N., Viñas, I., Usall, J., and Magan, N. 1998. Control of blue mold of apples by pre- harvest application of Candida sake grown in media with different water activity. Phytopathology 88:960-964.

23. Wilson, C. L., and Pusey, P. L. 1985. Potential for biological control of postharvest plant diseases. Plant Dis. 69:375-378.

24. Wisniewski, M. E., and Wilson, C. L. 1992 Biological control of postharvest diseases of fruits and vegetables: Recent advances. HortScience 27:94-98. 